\title{
Field testing of a vaccine against eel diseases caused by Vibrio vulnificus
}

\author{
Belén Fouz ${ }^{1}$, Maria Dolores Esteve-Gassent ${ }^{2}$, Rodolfo Barrera ${ }^{2}$, Jens Laurits Larsen ${ }^{3}$, \\ Michael Engelbrecht Nielsen ${ }^{3}$, Carmen Amaro ${ }^{1, *}$
}

\author{
${ }^{1}$ Departamento de Microbiología y Ecología, Facultad de Biología, Universidad de Valencia, Burjassot 46100, Spain \\ ${ }^{2}$ Valenciana de Acuicultura SA, Valencia 46530, Spain \\ ${ }^{3}$ Section of Fish Diseases, Department of Veterinary Microbiology, KVL, 1870-C Frederiksberg, Denmark
}

\begin{abstract}
The field results of a vaccination programme against Vibrio vulnificus serovar E (biotype 2) in a Spanish eel farm are reported. A total of 9.5 million glass eels were vaccinated from January 1998 to March 2000 by prolonged immersion followed by 2 subsequent reimmunisations after 12 to 14 and 24 to 28 d, respectively. The acquired protection and the immune response against serovar E were estimated over a period of 6 mo after vaccination. A similar vaccination schedule was conducted with elvers in a Danish eel farm. In this case, the acquired protection and the immune response against serovar E and the new eel-pathogenic serovars, recently described in Denmark, were evaluated over a short term. The overall results show that the vaccine against $V$. vulnificus serovar $\mathrm{E}$ induces a satisfactory protective immunity during the main growth period of eels (around 6 mo) with a relative percentage survival of 62 to $86 \%$ and protects them against the new eel-pathogenic serovars. Vaccination of eels by immersion seems to be the best strategy to prevent diseases caused by $V$. vulnificus.
\end{abstract}

KEY WORDS: Vibrio vulnificus serovar E · Vibrio vulnificus biotype 2 . Eel vaccines . Vibrio vaccines - Vaccination by prolonged immersion - Field vaccination. vibriosis

\section{INTRODUCTION}

Disease caused by the primary pathogen Vibrio vulnificus serovar E (formerly biotype 2) is the main cause of mortality in eels cultured in intensive systems, causing important economic losses (Austin \& Austin 1993, Biosca 1994, Dalsgaard et al. 1998, Høi 1999). The disease, in its acute form, has even provoked the closure of several farms in Europe and Canada (unpubl. data). The reason is that this serovar comprises highly virulent strains $\left(\mathrm{LD}_{50}\right.$ around $10^{2} \mathrm{CFU}$ fish ${ }^{-1}$ by the intraperitoneal route) (Biosca 1994) that can survive and be transmitted through water under favourable physicochemical conditions (Amaro et al. 1995). The pathogen is able to survive in eel blood and spread to the main

${ }^{*}$ Corresponding author. E-mail: carmen.amaro@uv.es body organs causing severe tissue damage (Biosca et al. 1993). The surface components specific to this serovar, lipopolysaccharide and capsule, enable cells to survive in serum (Amaro et al. 1994, Amaro et al. 1997), and proteases and haemolysins in extracellular products are responsible for tissue damage (Biosca \& Amaro 1996).

Recently, 2 new serovars of the species have been isolated from diseased eel in Denmark (Høi et al. 1998), serovars $\mathrm{O} 3$ and O3/O4. According to the serotyping system used by Martin \& Siebeling (1991), serovar E corresponds to serovar O4 (Høi et al. 1998). These new serovars produce different signs and seem to be secondary pathogens, since the source of the isolates was eel infected with either parasites or Pseudomonas anguilliseptica (Høi et al. 1998).

The efficacy of intensive medication to control the disease due to serovar E seems to be limited. Firstly, 
in the acute or sub-acute form of the disease, antibiotic treatments are of limited value. Secondly, resistant strains have been isolated and recurrent outbreaks have been registered after treatment with antibiotics (Biosca et al. 1991, Amaro et al. 1992, Biosca 1994, Høi 1999). Moreover, this practice may constitute a serious hazard to human health since Vibrio vulnificus serovar $\mathrm{E}$ is an opportunistic human pathogen (Amaro \& Biosca 1996) that survives in artificial seawater microcosms for years (Marco-Noales et al. 1999). Under this scenario, application of preventative measures, such as a programmed vaccination schedule, may enhance production with minimal use of antibiotics and associated risks for bacterial resistance. In fact, the success achieved during immunisation programmes against vibriosis caused by Listonella anguillarum and V. ordalii (Austin 1983, Smith 1988) suggests that an effective vaccine against $V$. vulnificus may be the best solution. We have recently developed and tested several vaccine formulations against $V$. vulnificus serovar E under controlled laboratory conditions (Collado et al. 2000). In that work we showed that (1) capsule and extracellular products were essential protective antigens, and that (2) a triple exposure to the vaccine by prolonged immersion was needed to ensure an acceptable level of protection, with relative percentage survival (RPS) of around $70 \%$ (Collado et al. 2000). From these results, we selected a toxoid-enriched bacterin prepared with capsulated cells.

The objective of this study was to develop an effective vaccination programme to be used in eel culture facilities to prevent epizootics caused by Vibrio vulnificus. Firstly, we immunised glass eels in a Spanish eel farm during a 2 yr period, and evaluated the immune response and protection in the short and long terms. Secondly, we followed a similar vaccination schedule with elvers in a Danish eel farm and evaluated the immune response and short term protection. In this case, we also tested the cross-protection against other serovars of the species that have been associated with eel diseases (Høi et al. 1998).

\section{MATERIAL AND METHODS}

Vaccine preparations. The vaccine was prepared according to the procedure described by Collado et al. (in press). Briefly, cells and extracellular products of strains of Spanish Collection of Type Cultures (CECT) 4604 and CECT 4605, representative of the 2 clones responsible for the epizootics registered in Spain (Biosca 1994), were inactivated by formalin and subsequently heated. The toxoid-enriched bacterin, named Vulnivaccine (licensed by the University of Valencia,
Spain; concession number 9701300), contained a final concentration of cells and proteins around 0.5 to 1 logarithmic units less than the original formulation (Collado et al. 2000). The quality-control protocols (sterility, lack of toxicity and absence of remaining enzymatic activities) were those outlined by Collado et al. (2000). We evaluated under controlled laboratory conditions the effectiveness of the vaccine by using 2 groups of 40 elvers (average weight $10 \mathrm{~g}$ ) exposed 3 times at $12 \mathrm{~d}$ intervals for $1 \mathrm{~h}$ to a 1:1000 dilution of the vaccine.

Field vaccination. Upon arrival at a Spanish eel farm, glass eels Anguilla anguilla (approximately $0.3 \mathrm{~g}$ ) were vaccinated by the following procedure. After quarantine, batches weighing 100 to $400 \mathrm{~kg}$ were vaccinated by immersion for 8 to $10 \mathrm{~h}$ with the vaccine diluted at 1:4000 to 1:8000 (Table 1). Water salinity was approximately $0.1 \%$ and the temperature was adjusted to $26 \pm 1^{\circ} \mathrm{C}$. The administration procedure was repeated twice under the same conditions at 12 to $14 \mathrm{~d}$ intervals. In the cases marked in Table 1, tanks with approximately $50 \mathrm{~kg}$ of non-vaccinated glass eels were maintained for 6 mo as control groups. Subsequently, these fish were also vaccinated and maintained in separate tanks. All groups of fish were fed a commercial diet that contained glucans (Trouvit Perla, Trouw S.A., Burgos, Spain). Fish were starved for $24 \mathrm{~h}$ before vaccination. A similar experiment was carried out at a Danish eel farm. In this case, 1 group containing $200 \mathrm{~kg}$ of elvers (weight average $2 \mathrm{~g}$ ) (A. anguilla) was vaccinated under similar conditions, while a nonvaccinated group of identical size was used as a control. Water salinity and temperature were approximately $0.3 \%$ and $26^{\circ} \mathrm{C}$, respectively.

Evaluation of immune response and protection. Fish were sampled to determine the degree of protec-

Table 1. Batches of glass eels used in the vaccination trials in Spain. ${ }^{*}$ Arrival date of fish into the culture facilities; ${ }^{ \pm}$Batches in which the immune response and level of protection were evaluated

\begin{tabular}{|ccc|}
\hline Year & $\begin{array}{c}\text { Date }^{*} \\
(\mathrm{mo} / \mathrm{d})\end{array}$ & $\begin{array}{c}\text { Vaccinated fish } \\
\left(\mathrm{kg} \mathrm{tank}^{-1}\right)\end{array}$ \\
\hline 1998 & $01 / 07$ & $218^{\text {T }}$ \\
& $02 / 03$ & 167 \\
& $06 / 05$ & $191^{\text {T }}$ \\
& $09 / 01$ & 192 \\
1999 & $09 / 30$ & 229 \\
& $11 / 20$ & 302 \\
& $01 / 26$ & $223^{\text {T }}$ \\
2000 & $03 / 30$ & 205 \\
& $07 / 27$ & $168^{\text {T }}$ \\
& $08 / 10$ & 148 \\
& $01 / 18$ & 412 \\
& $03 / 20$ & 389 \\
\hline
\end{tabular}


tion and the magnitude of specific immune response as follows: (1) in laboratory experiments, $12 \mathrm{~d}$ after vaccination; (2) in the Spanish eel farm, $15 \mathrm{~d}$ and 1, 2, 4 and 6 mo after vaccination; and (3) in the Danish farm, $12 \mathrm{~d}$ after each single vaccine dose. To calculate RPS (1 - [\% mortality in vaccinated fish/\% mortality in controls] $\times$ 100) (Amend 1981), groups of 40 fish from both vaccinated and control groups were challenged with the strain CECT 4604 following the methodology described by Amaro et al. (1995). The infective dose was equivalent to approximately 10 times $\mathrm{LD}_{50}$. To evaluate the immune response, serum and surface mucus samples (pooled from 6 to 8 fish) of vaccinated and unvaccinated fish were tested for antibody titres and bactericidal or bacteriostatic effect. Because of the small size of the eels, serum was sampled only from animals weighing more than $2 \mathrm{~g}$. Antibody titres against whole cells of serovar E (CECT 4604) were determined by an indirect ELISA according to Collado et al. (2000), and bactericidal or bacteriostatic activities were measured as the survival percentage of the same strain in these fluids after 0,1 and $3 \mathrm{~h}$ of incubation according to the procedure described by Amaro et al. (1999). To determine cross-protection against the other serovars, the RPS and the immune response of Danish eels against the strains 95-8-6 of serovar O3 (Høi et al. 1998) and 95-8161 of serovar O3/O4 (Høi et al. 1998) were evaluated by using the method described above.

Evaluation of protection against vibriosis in the field. When mortality due to Vibrio vulnificus in the experimental tanks was suspected, moribund fish were subjected to laboratory investigations to confirm the diagnosis. Moribund fish were necropsied and bacteriologically analysed according to Amaro et al. (1992). Bacterial strains were identified using the API20E (Biomerieux, France) system and this was confirmed serologically with sera against serovar E (Amaro et al. 1992). Both vaccinated and control groups of animals were given medication to avoid economic losses.

Finally, the presence of Vibrio vulnificus serovar E cells in water from affected tanks was monitored by indirect immunofluorescence. Volumes of 11 of water were fixed with $2 \%$ formalin (v/v), pre-filtered for debris elimination and filtered onto black $0.2 \mu \mathrm{m}$ pore sized polycarbonate filters (Milli- pore Corp., Bedford, MA, USA). Immune staining with antibodies against strain CECT 4604 was as described by Marco-Noales et al. (2000).

\section{RESULTS}

In laboratory experiments performed with Vulnivaccine, RPS after bath challenge with serovar E strain CECT 4604 was around $85 \%$ (Table 2). The antibody response against serovar $\mathrm{E}$ was moderate or poor, with mean antibody titres of 200 and 16 in sera and mucus, respectively (Table 2). A bactericidal effect was detected in mucus but not in serum (Table 2).

Afterwards, a vaccination programme of glass eels was established in a Spanish farm from 1998 to 2000 (Table 1). As shown in Table 3, RPS ranged from 62 to $86 \%$ (Table 3). The immune response was evaluated in parallel. As glass eels were small, serum was not sampled to measure its bactericidal activity or specific antibody titres. As expected, strain CECT 4604 was able to survive, and even multiply, in samples of mucus from

Table 2. Effectiveness of Vulnivaccine under laboratory conditions. *Vaccine was licensed under the name Vulnivaccine; ${ }^{ \pm}$Mean \pm SD $(n=3)$ of relative percentage of survival (RPS) between vaccinated and unvaccinated fish challenged by bath with strain CECT 4604 (Amaro et al. 1995); ${ }^{*}$ Antibody titres against bacterial strain CECT 4604 were determined by ELISA (Collado et al. 2000); ${ }^{\S} \mathrm{BaC}-$ tericidal and bacteriostatic activities were measured as the percentage survival of strain CECT 4604 after $3 \mathrm{~h}$ incubation in mucus or serum. +: survival percentage $<50 \%$; -: survival percentage $>100 \%$

\begin{tabular}{|lccccc|}
\hline Vaccine & $\begin{array}{c}\text { RPS }^{\ddagger} \\
(\%)\end{array}$ & \multicolumn{2}{c|}{ Antibody titre in } \\
& serum & surface mucus & \multicolumn{2}{c|}{$\begin{array}{c}\text { Bactericidal activity in } \\
\text { serum }\end{array}$} \\
surface mucus \\
\hline Vulnivaccine $^{*}$ & $84.6 \pm 5.2$ & 200 & 16 & - & + \\
Control & - & $<50$ & $<2$ & - & - \\
\hline
\end{tabular}

Table 3. Immune response and level of protection obtained in glass eels vaccinated by prolonged immersion in a Spanish farm. *Mean \pm SD of weight of vaccinated fish; ${ }^{ \pm}$RPS between vaccinated and unvaccinated fish challenged by bath with strain CECT 4604 (Amaro et al. 1995); ${ }^{*}$ Antibody titres against bacterial strain CECT 4604 were determined by ELISA according to Collado et al. $(2000) ;{ }^{\S}$ Bactericidal activity was measured as the percentage survival of strain CECT 4604 after $3 \mathrm{~h}$ incubation in surface mucus. +: 60 to 90 ; ++: 30 to 60 ; +++ : 5 to 30

\begin{tabular}{|lcccc|}
\hline $\begin{array}{l}\text { Post-vaccination } \\
\text { time (mo) }\end{array}$ & $\begin{array}{l}\text { Avg weight } \\
\text { of fish }(\mathrm{g})^{*}\end{array}$ & RPS $\left.^{\ddagger} \%\right)$ & $\begin{array}{c}\text { Antibody titre } \\
\text { in mucus }\end{array}$ & $\begin{array}{c}\text { Bactericidal activity } \\
\text { in mucus }\end{array}$ \\
\hline 0.5 & $0.34 \pm 0.005$ & $82 \pm 5$ & 4 & + \\
1 & $0.35 \pm 0.038$ & $72 \pm 4$ & 4 & + \\
2 & $0.44 \pm 0.066$ & $70 \pm 8$ & 4 & ++ \\
4 & $1.03 \pm 0.30$ & $75 \pm 4$ & $8-16$ & ++ \\
6 & $1.98 \pm 1.017$ & $80 \pm 6$ & 16 & +++ \\
\hline
\end{tabular}




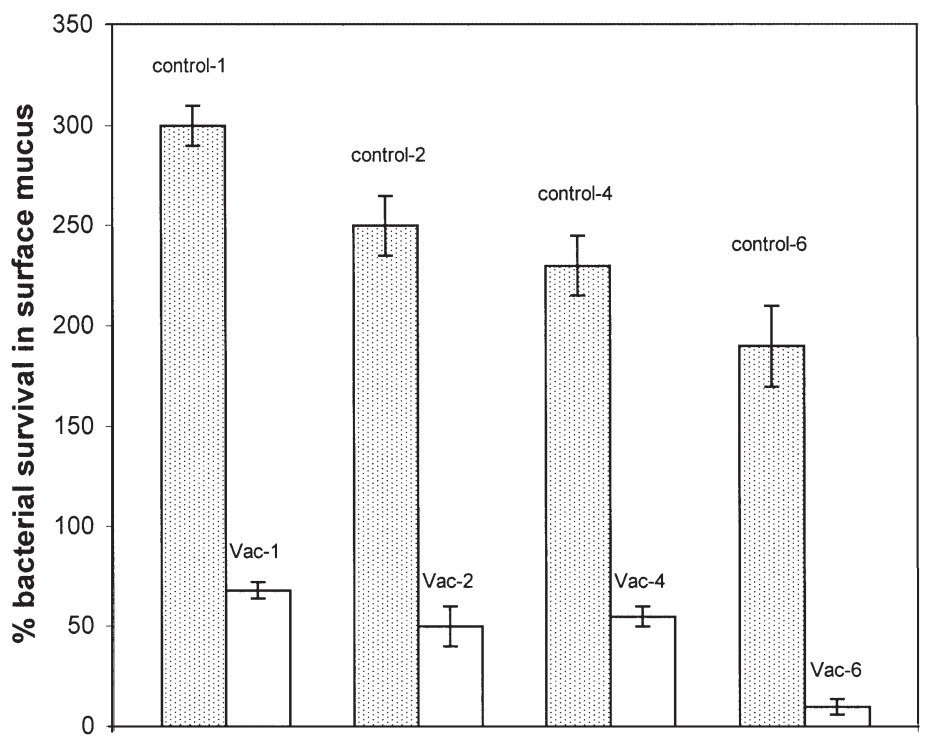

Fig. 1. Survival of strain CECT 4604 of Vibrio vulnificus serovar E $(\mathrm{O} 4)$ after $3 \mathrm{~h}$ incubation in surface mucus obtained from glass eels immunised (Vac) or not (control) with Vulnivaccine by prolonged immersion in a Spanish farm. Samples were taken 1, 2, 4 and 6 mo after vaccination. Mean values $\pm \mathrm{SD}(\mathrm{n}=3)$ are shown

unvaccinated glass eels (Fig. 1). However, the growth of this strain was inhibited by mucus from vaccinated glass eels, reaching the strongest inhibitory effects 6 mo after vaccination (Table 3, Fig. 1). The antibody response was poor, with titres ranging from 4 to 16 , with the highest values detected 5 to 6 mo after vaccination (Table 3).

Two outbreaks due to Vibrio vulnificus serovar E were registered in the Spanish farm during the study period: in July 19982 weeks after an increase in water temperature (up to $30^{\circ} \mathrm{C}$ ) and nitrite concentrations, and in December 1999 after an increase in nitrite and $\mathrm{pH}$ (from 5.5 to 7). The first outbreak affected only nonvaccinated fish and was controlled by treatment with oxolinic acid in water (8 ppm for $5 \mathrm{~d}$ followed by $2.5 \mathrm{ppm}$ for $10 \mathrm{~d})$. The second episode affected fish vaccinated in 1998 but not those vaccinated in 1999. The problem was controlled by 3 baths with tetracycline (25 ppm) at intervals of 4 to $5 \mathrm{~d}$. In both cases, water salinity was around 0.15 to $0.2 \%$ and $V$. vulnificus serovar E was not detected in water by immunofluorescence before antibiotic treatments. We could not compare mortality rates between vaccinated and control groups because both were medicated.

In the vaccination experiments performed in Denmark, elvers were also well protected against Vibrio vulnificus serovar E, showing RPS around $85 \%$ after $12 \mathrm{~d}$ of the vaccination schedule (Table 4). The mucus antibody titres were similar to those observed in mucus of glass eels and was also bactericidal (Table 4). In this case, the immune response in serum from vaccinated fish could be analysed because elvers weighed more than $2 \mathrm{~g}$, and we found a clear bactericidal effect together with high antibody titres against serovar E (Table 4).

The cross-protection of vaccinated elvers against serovars $\mathrm{O} 3$ and $\mathrm{O} 3 / \mathrm{O} 4$, recently associated with eel disease, was also evaluated in Denmark. None of the new serovars was virulent by bath immersion ( $\mathrm{LD}_{50}$ higher than $\left.10^{8} \mathrm{CFU} \mathrm{m}{ }^{-1}\right)$, so that we could not calculate the RPS. However, when mucus and serum were tested, they showed bacteriostatic or bactericidal effects against both serovars (Figs $2 \& 3$ ).

\section{DISCUSSION}

The laboratory vaccination assays showed that Vulnivaccine was effective in protecting elvers against Vibrio vulnificus serovar E. The RPS values were higher than those previously obtained with other toxoid-enriched bacterins (Collado et al. 2000). Since the main modification in the formulation of Vulnivaccine was the reduction in concentration of both cells and

Table 4. Immune response and level of protection obtained in the short term in elvers vaccinated by prolonged immersion in a Danish eel farm. ${ }^{*}$ Mean \pm SD of the weight of vaccinated fish ${ }^{{ }^{\top}}$ Mean \pm SD of the RPS between vaccinated and unvaccinated fish challenged by bath with strain CECT 4604 (Amaro et al. 1995); ${ }^{\ddagger}$ Mean \pm SD of antibody titres against bacterial strain CECT 4604 (determined by ELISA); ${ }^{\S}$ Bactericidal activity was measured as the percentage survival of strain CECT 4604 after $3 \mathrm{~h}$ incubation. +: 80 to $90 ;++: 40$ to $80 ;+++: 5$ to 40 . ND: not done

\begin{tabular}{|lcccccc|}
\hline $\begin{array}{l}\text { Time after first } \\
\text { vaccination (d) }\end{array}$ & $\begin{array}{c}\text { Average weight } \\
\text { of eels }(\mathrm{g})^{*}\end{array}$ & $\begin{array}{c}\mathrm{RPS}^{\ddagger} \\
(\%)\end{array}$ & \multicolumn{2}{c}{$\begin{array}{c}\text { Antibody } \\
\text { serum }\end{array}$} & $\begin{array}{c}\text { titres in } \\
\text { mucus }\end{array}$ & \multicolumn{2}{c|}{$\begin{array}{c}\text { Bactericidal activity in } \\
\text { serum }\end{array}$} & $\begin{array}{c}\text { mucus } \\
\text { sum }\end{array}$ \\
\hline 0 & $1.90 \pm 0.85$ & ND & $800 \pm 200$ & ND & ND & ND \\
12 & $2.09 \pm 0.95$ & ND & $5700 \pm 1500$ & ND & ND & ND \\
24 & $2.39 \pm 0.81$ & ND & $7000 \pm 800$ & ND & ND & ND \\
36 & $2.93 \pm 1.20$ & $83 \pm 4$ & $9300 \pm 1000$ & $3 \pm 1$ & +++ & + \\
\hline
\end{tabular}


toxoids, lower concentrations of antigens seem to improve the immune response in eel. In agreement with the results obtained by Collado et al. (2000) we detected a bactericidal effect in mucus of immersion-vaccinated elvers but not in serum. Thus, the bactericidal effect of mucus prevented disease in 1 of the first steps, probably the colonisation.

When experiments with Vulnivaccine were carried out with both glass eels and elvers in fish farms, vaccinated fish were well protected against Vibrio vulnificus serovar E, showing RPS close to those found in elvers vaccinated in the laboratory. In the case of glass eel, the protective effect lasted at least 6 mo after vaccination. A similar degree of protection has also been reported in Baltic salmon smolts, 4 mo after immersion vaccination with a triple bacterin containing formalin-killed Listonella anguillarum, Aeromonas salmonicida and Yersinia ruckeri (Buchmann et al. 1997). The protection conferred by Vulnivaccine can be extended to the new pathogenic serovars since we detected a bactericidal effect in mucus and serum of farmed vaccinated fish against serovars O3 and O3/O4. The immune response against serovar $\mathrm{E}$ in the short term in mucus from glass eels and elvers was similar to that found in elvers vaccinated in the laboratory, since they showed low antibody concentrations and a bactericidal effect. This effect persisted in glass eels, reaching the highest level 6 mo after vaccination. Similar titres have been obtained by other authors, who rarely detected specific antibodies in skin mucus from immunised fish (Cobb et al. 1998). The immune response in serum from glass eel could not be evaluated because their small size made sampling difficult. When field trials were carried out with elvers, we sampled serum and detected a clear bactericidal effect and high antibody titres against serovar E. Compared with the results obtained in laboratory vaccination, the specific immune response in serum was higher. One of the reasons may be that the feed intake under laboratory conditions is much lower due to the stress associated with the transportation and adaptation to the new maintenance conditions (unpubl. obs.). This result suggests that the feed is very important to the development of an optimal immune status in eel.

The bactericidal effect detected in vaccinated fish in farms was directly related to high titres of specific antibodies in serum but not in mucus. Perhaps low concentrations of antibodies are sufficient to activate the complement in mucus or, more probably, we underestimated antibody titres because in our ELISA we use anti-eel serum immunoglobulin as a secondary antibody. In any case, our results support the important role of antibodies in the defence of eel against Vibrio vulnificus serovar E. In fact, circulating antibodies have been established as the principal protective immune response against extracellular bacteria in higher vertebrates (Abbas et al. 1991). These antibodies may also be present in mucus and act as a primary line of defence against $V$. vulnificus, as has been suggested for other pathogens (Rombout et al. 1986, Austin \& McIntosh 1988, Itami 1993).

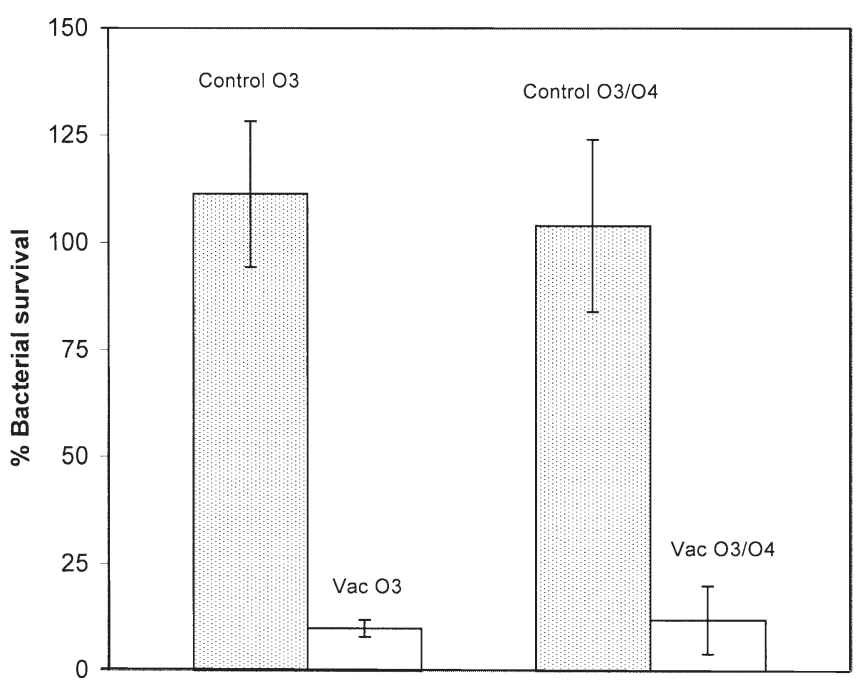

Fig. 3. Survival of strains 95-8-6 serovar O3 and 95-8-161 serovar O3/O4 of Vibrio vulnificus after $3 \mathrm{~h}$ incubation in serum obtained from elvers immunised (Vac) or not (Control) with Vulnivaccine by prolonged immersion in a Danish farm. Mean values $\pm \operatorname{SD}(n=3)$ are shown 
Finally, 2 outbreaks due to Vibrio vulnificus serovar E were registered in the Spanish farm during the study period. Although we could not compare mortality rates between vaccinated and control groups, it should be emphasised that the disease did not affect the animals vaccinated within the previous 6 mo. These results were quite satisfactory and confirmed that Vulnivaccine effectively protected eels against natural disease due to $V$. vulnificus serovar E for at least 6 mo following vaccination. The pathogen was not detected in water by immunofluorescence during the outbreaks. This result may indicate that the bacterium was not present in water, as has already been suggested by other authors (Arias 1998) who did not succeed in isolating it from water tanks during outbreaks. In theory, the salinity ( 0.15 to $0.2 \%$ ) was too low to favour the survival and the spread of $V$. vulnificus (Amaro et al. 1995), and the disease may have been transmitted by direct contact between animals. However, it is also possible that the bacterium was present in low numbers or associated with particulate material. In this case, the isolation methods would need to be modified to isolate the bacterium.

In summary, our results show that Vulnivaccine, delivered by prolonged immersion, induces a protective response to Vibrio vulnificus serovar E (serovar O4) in vaccinated glass eels and elvers on a large scale. This vaccine may also protect against serovars $\mathrm{O} 3$ and $\mathrm{O} 3 / \mathrm{O} 4$. As the vaccine induces protection in fish during the main growth period, vaccination of glass eels by immersion on delivery to the culture facilities may be the best strategy to prevent $V$. vulnificus diseases. Work on eel protection by oral vaccination is in progress.

Acknowledgements. This work has been financed by the Spanish projects PETRI 95-0070-OP and CICYT IFD97-0800 from Ministerio de Educación y Ciencia and the Danish Project 'Elizabeth and Knud Petersens Fond'. M.D.E.-G. thanks the Leonardo Da Vinci European Program and the Ministerio de Educación y Ciencia for a pre-doctoral fellowship supporting her investigations in the fish farm (BECAS MIT). We thank Rafael Ruano and José Tornero from the Generalitat Valenciana for supplying eels for immunisation. We also thank Barraclough-Donnellan for their help with the English text.

\section{LITERATURE CITED}

Abbas AK, Litchtman AH, Pober JS (1991) Cellular and molecular immunology. WB Saunders Company, Philadelphia.

Amaro C, Biosca EG (1996) Vibrio vulnificus biotype 2, pathogenic for eels, is also an opportunistic pathogen for humans. Appl Environ Microbiol 62:1454-1457

Amaro C, Biosca EG, Esteve C, Fouz B, Toranzo AE (1992) Comparative study of phenotypic and virulence properties in Vibrio vulnificus biotype 1 and 2 obtained from a European eel farm experiencing mortalities. Dis Aquat Org 13: 29-35

Amaro C, Biosca EG, Fouz B, Toranzo AE, Garay E (1994) Role of iron, capsule, and toxins in the pathogenicity of Vibrio vulnificus biotype 2 for mice. Infect Immun 62: 759-763

Amaro C, Biosca EG, Fouz B, Alcaide E, Esteve C (1995) Evidence that water transmits Vibrio vulnificus biotype 2 infections to eels. Appl Environ Microbiol 61:1133-1137

Amaro C, Fouz B, Biosca EG, Collado RM, Marco-Noales E (1997) The lipopolysaccharide O side chain of Vibrio vulnificus serogroup $\mathrm{E}$ is a virulence determinant for eels. Infect Immun 65:2475-2479

Amaro C, Hor L, Marco-Noales E, Bosque T, Fouz B, Alcaide E (1999) Isolation of Vibrio vulnificus serovar $E$ from aquatic habitats in Taiwan. Appl Environ Microbiol 65: 1352-1355

Amend D (1981) Potency testing of fish vaccines. Dev Biol Stand 49:447-454

Arias CR (1998) Detección y tipificación de Vibrio vulnificus por técnicas moleculares. $\mathrm{PhD}$ thesis, Universidad de Valencia

Austin A (1983) Vaccine for the control of vibriosis in eels. Vet Rec 22:394-395

Austin B, Austin DA (1993) Vibrionaceae representatives. In: Laird LM (ed) Bacterial fish pathogens. Ellis Horwood Ltd, Chichester, p 265-294

Austin B, MacIntosh D (1988). Natural antibacterial compounds on the surface of rainbow trout, Salmo gairdneri Richardson. J Fish Dis 11:275-277

Biosca EG (1994) Serología y virulencia de Vibrio vulnificus biotipo 2. PhD thesis, Universidad de Valencia

Biosca EG, Amaro C (1996) Toxic and enzymatic activities of Vibrio vulnificus biotype 2 with respect to host specificity. Appl Environ Microbiol 62:2331-2337

Biosca EG, Amaro C, Esteve C, Alcaide E, Garay E (1991) First record of Vibrio vulnificus biotype 2 from diseased European eel, Anguilla anguilla L. J Fish Dis 14:103-109

Biosca EG, Llorens H, Garay E, Amaro C (1993) Presence of a capsule in Vibrio vulnificus biotype 2 and its relationship to virulence for eels. Infect Immun 61:1611-1618

Buchmann K, Dalsgaard I, Nielsen ME, Pedersen K, Uldal A, García JA, Larsen JL (1997) Vaccination improves survival of Baltic salmon (Salmo salar) smolts in delayed release sea ranching (net-pen period). Aquaculture 156: $335-348$

Cobb CS, Levy MG, Noga EJ (1998) Acquired immunity to amyloodiniosis is associated with an antibody response. Dis Aquat Org 34:125-133

Collado RM, Fouz B, Amaro C (2000) Effectiveness of different vaccine formulations against vibriosis caused by Vibrio vulnificus serovar E (biotype 2) in European eels (Anguilla anguilla). Dis Aquat Org 43:91-101

Dalsgaard I, Hoi L, Siebeling RJ, Dalsgaard A (1998) Indolepositive Vibrio vulnificus isolated from disease outbreaks on a Danish eel farm. Dis Aquat Org 35:187-194

Høi L (1999) Vibrio vulnificus in Denmark, occurrence, isolation and characterization. PhD thesis. Department of Veterinary Microbiology. The Royal Veterinary and Agricultural University, Copenhagen

Høi L, Dalsgaard I, DePaola, A, Siebeling RJ, Dalsgaard A (1998) Heterogeneity among isolates of Vibrio vulnificus recovered from eels (Anguilla anguilla) in Denmark. Appl Environ Microbiol 64:4676-4682

Itami I (1993) Defense mechanism of Ayu skin mucus. J Shimonoseki Univ Fish 42:1-71 
Marco-Noales E, Biosca EG, Amaro C (1999) Effect of salinity and temperature on the long-term survival of the eel pathogen Vibrio vulnificus biotype 2 (serovar E). Appl Environ Microbiol 65:1117-1126

Marco-Noales E, Biosca EG, Milán M, Amaro C (2000) An indirect immunofluorescent antibody technique for detection and enumeration of Vibrio vulnificus serovar E (biotype 2): development and applications. J Appl Microbiol 89:599-606

Martin SJ, Siebeling RJ (1991) Identification of Vibrio vulnifi-

Editorial responsibility: David Bruno,

Aberdeen, Scotland, UK cus O serovars with anti-lipopolysaccharide monoclonal antibodies. J Clin Microbiol 29:1684-1688

Rombout JWHM, Berg AA, van Berg CTGA, van de Witte P, Egberts E (1986) Immunization of carp (Cyprinus carpio) with Vibrio anguillarum bacterin: indications for a common mucosal immune system. Dev Comp Immunol 10: $341-351$

Smith PD (1988) Vaccination against vibriosis. In: Ellis AE (ed) Fish vaccination. Academic Press Limited, London, p 67-84

Submitted: November 10, 2000; Accepted: April 9, 2001

Proofs received from author(s): July 16, 2001 